\title{
The year of transparency: measuring quality of cardiac care
}

\author{
D.C. Eindhoven $\cdot$ E. Wierda $\cdot$ M.C. de Bruijne $\cdot$ \\ G. Amoroso · B.A.J.M. de Mol • V.A.W.M. Umans • \\ M.J. Schalij · C.J.W. Borleffs
}

Published online: 14 August 2015

(C) The Author(s) 2015. This article is published with open access at Springerlink.com

\begin{abstract}
The assessment of quality of care is becoming increasingly important in healthcare, both globally and in the Netherlands. The Dutch Minister of Health declared 2015 to be the year of transparency, thereby aiming to improve quality of care by transparent reporting of outcome data. With the increasing importance of transparency, knowledge on quality measurement will be essential for a cardiologist in daily clinical care. To that end, this paper provides a comprehensive overview of the Dutch healthcare structure, quality indicators and the current and future assessment of quality of cardiac care in the Netherlands.
\end{abstract}

Keywords Quality of healthcare - Quality indicators · Cardiovascular outcomes · Transparency

D.C. Eindhoven and E. Wierda contributed equally to this article and therefore share authorship.

M.J. Schalij $(\square) \cdot$ D.C. Eindhoven · C.J.W. Borleffs Department of Cardiology, Leiden University Medical Center, PO Box 9600, 2300 RC Leiden, The Netherlands

e-mail: m.j.schalij@lumc.nl

E. Wierda $\cdot$ G. Amoroso

Department of Cardiology, Onze Lieve Vrouwe Gasthuis,

Amsterdam, The Netherlands

M.C. de Bruijne

Department of Public and Occupational Health, EMGO Institute for Health and Care Research, VU University Medical Center, Amsterdam, The Netherlands

B.A.J.M. de Mol

Department of Cardiothoracic Surgery,

Academic Medical Center,

Amsterdam, The Netherlands

V.A.W.M. Umans

Department of Cardiology, Medical Center Alkmaar,

Alkmaar, The Netherlands

\section{Introduction}

The assessment of quality of care is becoming increasingly important in healthcare, both globally and in the Netherlands. With the transition into a regulated healthcare market system in 2006, insurance companies received a central role and the shared legal responsibility for the quality of costeffective care. This responsibility created the legal need to develop a system in which quality of care can be measured and monitored [1]. Currently, hospital accreditation is already based on quality measurements and in the future, reimbursement will most likely be based on quality instead of price and volume only [2]. The Dutch Minister of Health has declared the year 2015 to be the year of transparency, thereby stressing the need for reporting of measurable quality of care $[3,4]$. With the increasing importance of transparency, knowledge on quality measurement will become vital in daily clinical care. The current manuscript provides a comprehensive overview of the Dutch healthcare structure, quality indicators and the current and future assessment of quality of care in the Netherlands.

\section{Definition of quality indicators}

Quality of care has been defined by the Agency for Healthcare Research and Quality of the United States as doing the right thing, at the right time, in the right way, for the right person — and having the best possible results [5]. The aim of measuring quality of care changes with the different positions in the healthcare system [6]. Patients aim for the best possible outcome and need quality measurements to be able to take informed decisions. Healthcare professionals aim for the best possible outcome for a maximum number of patients and, additionally, need quality measurements to benchmark results with other healthcare professionals in 


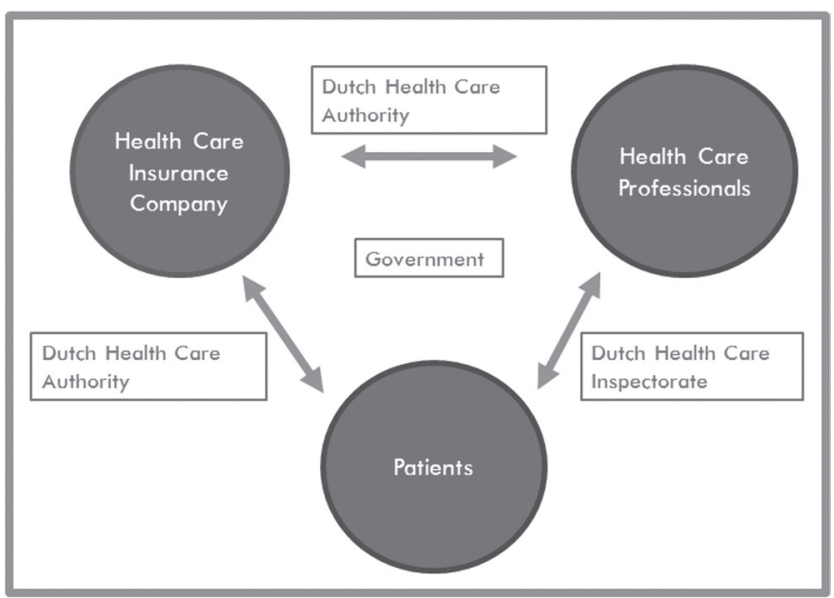

Fig. 1 Different positions in the health care system in the Netherlands

order to identify room for improvement. Healthcare insurance companies aim for the best possible (long-term) value for the money spent on behalf of their customers (insured patients). The government aims to achieve the best possible public health at a stated budget, while guaranteeing financial and physical accessibility and affordability for all inhabitants ([7]; Fig. 1).

To accomplish all these goals, quality of care has to be measured. In 1966, Donabedian described three different types of measurable indicators for quality of care: structure, process and outcome indicators ([8]; Tab. 1).

Structure indicators reflect the system and setting in which care is delivered and measurements relate directly or indirectly to staff expertise or the organisation. For cardiac care, examples are PCI volume, availability of a catheterisation laboratory and the educational level of the nursing staff. Structure indicators are less likely to be influenced by medical professionals and therefore less useful to monitor programs for quality improvement. They reflect the average results for large groups of providers, not individuals. The advantage of these structure indicators is that they are expedient and inexpensive to collect and can be used in plain hospital comparisons. Structure indicators are in general of limited use in clinical practice although recently a large study $(n=457,498)$ was published in which a relationship was found between increased operator/institutional volume of PCI procedures and a decrease in adverse outcomes and cost of hospitalisation [9]. However, other studies demonstrated that an increase of volume above a certain threshold is not related to improved outcomes, hence some of these structure indicators may be useful to define minimal requirements.

Process indicators describe the care patients actually receive. Examples for cardiac care are door-to-balloontimes in patients with a ST-segment elevation myocardial infarction and medication prescription according to the guidelines $[10,11]$. The usefulness of process indicators and the association with clinical outcome measures has been thoroughly established. In patients with myocardial infarction, Peterson et al. showed a correlation between processes of care and outcome. With every $10 \%$ increase in process adherence (for example medication use according to guidelines) there was an associated $10 \%$ decrease in in-hospital mortality [10]. Another study demonstrated $6 \%$ of hospitallevel variation of 30-day mortality rate to be explained by the performance on process measures [12]. In heart failure, the relationship between process and outcome is however modest. In the OPTIMIZE-HF study, none of the process measurements were associated with a decrease in 60 - or 90-day mortality [13]. In case of a proven association, process indicators can be useful to monitor if aspects of clinical practice result in an improvement of the quality of care. A limitation, however, is that evidence on which processes are important for specific procedures is scarce. Importantly, although the use of process indicators is known to be effective in general, they do not mark the quality of care in individual patients. For example, patients with symptomatic bradycardia after myocardial infarction should not receive a beta-blocker, stressing the need for a connection with clinical data, which is more time-consuming.

Quality of care is most effectively measured by clinical outcome measures, referring to the effect of the provided care on the health status of patients: outcome indicators. Examples of these are overall mortality rate, hospital readmission rate, functional health status and patient satisfaction. Outcome measurement is considered the most important measurement of quality of care but has to be acquired per patient and is therefore relatively time-consuming and expensive. In 2013, the Court of Audit (Algemene Rekenkamer) concluded that the quality of most indicator sets is limited and that only $7 \%$ of the indicators collected by hospitals were outcome indicators [14].

\section{Registration in cardiology in the Netherlands}

\section{National quality measurement}

National quality measurements are initiatives from government, supervision institutions, insurance companies and patient organisations. From the perspective of the individual hospital and/or cardiology department these initiatives can be judged to be external requests for accountability.

The Dutch Healthcare Inspectorate (Inspectie voor de Gezondheidszorg, IGZ) has an important task, as described in Article 36 of the Healthcare Insurance Act, to verify if hospitals meet the minimum level of quality according to general healthcare acts and the professional standards as defined by the different medical specialists [4]. Verification is achieved by surveillance of compliance to the law, 
Table 1 Advantages and disadvantages of outcome, structure and process indicators

\begin{tabular}{|c|c|c|c|}
\hline & Structure indicators & Process indicators & Outcome indicators \\
\hline \multirow[t]{4}{*}{$\overline{\text { Example }}$} & PCI volume a year & $\begin{array}{l}\text { Medical prescription according } \\
\text { to guidelines }\end{array}$ & Morbidity and mortality \\
\hline & Availability of cathlab & Door-to-balloon-times & Functional health status \\
\hline & Education level of the nurses & & Patient satisfaction \\
\hline & & & Costs \\
\hline \multirow[t]{3}{*}{ Advantages } & Appropriate & $\begin{array}{l}\text { Reflect care that patients actu- } \\
\text { ally receive }\end{array}$ & The 'bottom-line' of cardiology \\
\hline & $\begin{array}{l}\text { If associated with outcome, inexpensive } \\
\text { proxies of cardiological outcomes }\end{array}$ & $\begin{array}{l}\text { Actionable from provider } \\
\text { perspective }\end{array}$ & $\begin{array}{l}\text { Outcomes measurement alone may } \\
\text { improve outcomes }\end{array}$ \\
\hline & & $\begin{array}{l}\text { Clear link to quality improve- } \\
\text { ment activities }\end{array}$ & \\
\hline \multirow[t]{2}{*}{ Disadvantages } & $\begin{array}{l}\text { Most variables not actionable from } \\
\text { provider perspective }\end{array}$ & $\begin{array}{l}\text { Little information about which } \\
\text { processes are important for } \\
\text { specific procedures }\end{array}$ & $\begin{array}{l}\text { Numbers too small to measure with } \\
\text { adequate procedure-specific outcomes } \\
\text { for most hospitals and procedures }\end{array}$ \\
\hline & $\begin{array}{l}\text { Imperfect proxies for outcomes reflect } \\
\text { average results for large groups of pro- } \\
\text { viders, not individuals }\end{array}$ & & $\begin{array}{l}\text { Outcome measures that are not proce- } \\
\text { dure-specific less useful for purposes of } \\
\text { quality improvement }\end{array}$ \\
\hline
\end{tabular}

Based on table from Birkmeyer (2004) which is applied on examples from Cardiology [43].

regulations, professional standards and guidelines. The Dutch Healthcare Inspectorate focuses on surveillance of the highest risks by mostly collecting process and structure indicators as delivered by the healthcare providers. For ST-segment elevation myocardial infarction, outcome, structure and process indicators (number of PCI procedures, in-hospital or 30-day mortality, door-to-needle time or doorto-balloon time and the percentage of patients referred for cardiac rehabilitation) are acquired. For pacemaker and implantable cardioverter defibrillator implantations the number of procedure-related complications within 90 days has to be registered [15]. The Safety Management System (Veiligheidsmanagementsysteem, VMS) is a Dutch patient safety program started by the Ministry of Health, Welfare and Sport and supported by all hospitals, primarily initiated to reduce avoidable patient injuries during hospital admission. These VMS indicators are now (partly) incorporated in the indicators collected by IGZ.

Hospitals use external accreditation programs to prove and objectify a certain level of quality of care as well as maintenance of quality of care to outsiders. The Netherlands Institute for Accreditation in Healthcare (Nederlands Instituut voor Accreditatie in de Zorg, NIAZ) aims to assure and improve Dutch healthcare by using an international accreditation program in which amongst others the VMS indicators are embedded. Some hospitals in the Netherlands use the international accreditation program, such as the Joint Commission International. Besides quantitative quality indicators, the accreditation systems comprise explicit quality policies and quality instruments, such as incident reporting and audits.

As described in the introduction, the Dutch healthcare system changed in 2006, aiming to reduce rising healthcare costs while improving quality of care. In order to achieve this, the Dutch government introduced a regulated healthcare market. Two new important acts were introduced: the Healthcare Insurance Act (Zorgverzekeringswet) and the Act of Regulation of Healthcare (Wet Marktordening Gezondheidszorg) $[4,16]$. In the new system the health insurance companies play a central role, positioned between patients and caregivers, with a shared responsibility to ensure good quality and cost-effective care. For the first time it became possible for the insurance companies to selectively contract. Additional to the responsibility in limiting the rising healthcare costs, insurance companies are required to analyse and interpret quality of care provided by caregivers. Article 14 of the Healthcare Insurance Act, and the general directorial based on this, states that insurance companies share the responsibility for efficient and timely healthcare of good quality, based on professional standards defined by the scientific professional organisations and healthcare providers. The explanatory memorandum of the act states that more information on outcome of caregivers will be available in the future [17]. Currently, however, more attention is given to the volume and cost agreement than to the provided quality of care [18, 19]. The Dutch Healthcare Authority (Nederlandse Zorgautoriteit, NZa), with its task of overseeing the regulated healthcare market, is positive about the increased attention to quality of care in contracting during recent years [20]. A recent report of the Council for Public Health and Healthcare (Raad voor de Volksgezondheid en Zorg, RVZ) concluded that health insurance companies have to be more transparent about the criteria used for contracting care, which caregivers are contracted and how patients were involved in the process of contracting [21]. 
National quality registries in cardiology

When focussing on cardiology in the Netherlands, there are three large national registries: (1) the National Cardiovascular Data Registry (NCDR), (2) the Supervisory Committee for Heart Interventions in the Netherlands (Begeleidingscommissie Hartinterventie Nederland, BHN) and (3) Meetbaar Beter. These registries are all initiated by the healthcare professionals involved and funded by the participating hospitals. From the perspective of the hospital and cardiology department, these initiatives can be regarded as internal quality initiatives, primarily meant to improve the internal quality of the individual healthcare provider. Increasingly, on request of the government, Healthcare Inspectorate, insurance companies and patient organisations, these registers are used for external accountability as well. The NCDR was initiated by the Netherlands Society of Cardiology (Nederlandse Vereniging voor Cardiologie, NVVC) and organised in steering committees to develop different databases for every area in cardiology [22]. Furthermore, the NCDR data are sent to the national Implant Register (Medisch Implantatenregister), recently initiated by the Ministry of Health, Welfare and Sport [23]. The NCDR is NEN7510 certified, an information security certificate. Currently, data of more than 250,000 device patients are registered and almost all hospitals (85) participate in NCDR. The BHN, a collaboration of cardiothoracic surgery, cardiology, anaesthesiology and paediatric cardiology, is a national registry of cardiac interventions. The BHN includes data of all 16 cardiothoracic centres since 2007 [24]. Meetbaar Beter, initiated by the Catharina Hospital, Eindhoven and the St. Antonius Hospital, Nieuwegein, is a collaboration of currently 12 cardiothoracic centres in the Netherlands. In the near future Meetbaar Beter will also include data from PCI centres without on-site heart surgery. The Meetbaar Beter initiative raises a new Dutch concept of transparency reporting: a patient-oriented and physician-driven registry. Meetbaar Beter registers patient-outcome data in order to optimise clinical processes. Annually, these outcome indicators are analysed and when required, improvements are established [25]. Besides these national initiatives, in 16 out of 25 regions in the Netherlands, cardiologists collaborate with general practitioners, emergency services and patient representatives in a regional context which is called NVVC Connect. NVVC Connect aims to optimise regional care for myocardial infarction, atrial fibrillation and heart failure patients [26].

\section{International registries}

The first initiatives to register the quality of cardiac care on a national basis were started in Sweden and the United States. Currently, the Swedish registry SWEDEHEART collects data from all 74 hospitals in Sweden. In the United States, the American College of Cardiology (ACC) initiated the National Cardiovascular Data Registry (NCDR ${ }^{\circledR}$ CathPCI), which contains information on 12 million patients from 1577 participating centres [27]. England and Wales collect information in the Myocardial Ischaemia National Audit Project (MINAP)/National Institute for Cardiovascular Outcomes Research (NICOR) database on all patients with acute coronary syndrome, which contains data from all 236 hospitals $[28,29]$. These registries are useful instruments for addressing important clinical questions by retrospectively selecting patients for a randomised trial [30]. An overview of other international AMI registries is given in Tab. 2. It emphasises that sufficient funding is important to ensure a solid registry.

\section{The relationship between registration of quality indicators and patient outcomes}

Since registration is a time-consuming process, it is important to ascertain whether the used quality indicators actually provide the desired effect of improving quality of care. Chatterjee et al. have described three mechanisms by which registrations can help to improve patient outcomes [31].

First of all, reporting about quality of care in cardiology itself can lead to an incentive for hospital leaders and clinicians for improvement. In order to achieve this, it is important that results can be shared safely. Studies show that by paying attention internally to quality of care, improvement in outcomes of healthcare can be observed, which is called the Hawthorne effect [32].

Public reporting can also be a powerful incentive for clinicians and hospital leaders to improve. Besides, transparency increases confidence of patients in the healthcare system. However, public reporting of quality indicators in the United States also demonstrated some disadvantages. First of all, some studies comparing reporting states and non-reporting states show no differences in outcome [33]. A further concern of public reporting is that it will lead to risk aversion among physicians, deferring patients with more complex pathology, as is demonstrated in the literature. For example, in the United States, the majority $(89 \%)$ of interventional cardiologists have reported that the decision to intervene in critically ill patients was influenced by participating in the reporting of quality measures [33]. A registry confirmed this trend in practice, showing that patients in reporting states (e.g. New York) were less likely to undergo a PCI procedure if they were in shock [34]. Public reporting of CABG mortality in New York led to an increase of sicker patients being referred to the adjacent state Ohio [35]. Although transparency in quality indicators is increasing in the Netherlands, currently results cannot be linked to individual caregivers. The Society for Cardiothoracic Surgery in Great Britain and Ireland, in collaboration with 


\section{Advertisement placed here.}

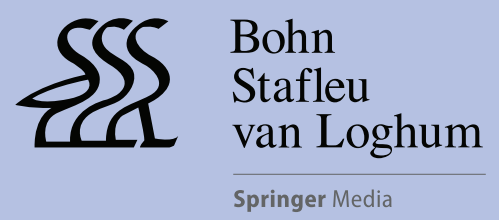

Houten 2015 


\title{
Advertisement placed here.
}

\author{
cC Bohn

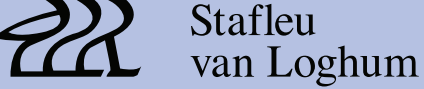 \\ Springer Media
}

Houten 2015 
Tab. 2 Overview of internal registries in Cardiology internationally, focussed on AMI registries

\begin{tabular}{|c|c|c|c|}
\hline Country & National registry & Founded & Remarks \\
\hline \multirow[t]{2}{*}{ Belgium } & $\begin{array}{l}\text { Belgian STEMI project }[44,45] \\
\text { BIWAC, Belgian Interdisciplin- } \\
\text { ary Working Group on Acute } \\
\text { Cardiology }\end{array}$ & 2007 & $\begin{array}{l}\text { Covering: obligatory for all Belgian hospitals; } 50-60 \% \text { STEMI patients a } \\
\text { year are registrated } \\
\text { Details: } 3000 \text { patients a year } \\
\text { Variables: } 25-30 \\
\text { Funding: Public, not linked with reimbursement }\end{array}$ \\
\hline & $\begin{array}{l}\text { PCI registry [46] } \\
\text { BWGIC, Belgian Working Group } \\
\text { Interventional Cardiology }\end{array}$ & & $\begin{array}{l}\text { Covering: all PCI hospitals } \\
\text { Funding: Public, linked with a minimal reimbursement on PCI material }\end{array}$ \\
\hline England/Wales & $\begin{array}{l}\text { MINAP }[28,29] \\
\text { Myocardial Ischaemia National } \\
\text { Audit Project }\end{array}$ & 2000 & $\begin{array}{l}\text { Covering: all } 236 \text { acute hospitals in England and Wales for ACS patients } \\
\text { (STEMI and NSTEMI) } \\
\text { Details: } 735000 \text { patients (2010) } \\
\text { Variables: } 123 \\
\text { Funding: Public, by participating hospitals }\end{array}$ \\
\hline France & $\begin{array}{l}\text { FAST-MI }[47,48] \\
\text { French registry of Acute } S T \text { - } \\
\text { segment elevation or non-ST- } \\
\text { segment elevation Myocardial } \\
\text { Infarction }\end{array}$ & 2005 & $\begin{array}{l}\text { Covering: } 223 \text { centres }(60 \%) \text {. Data collection every five years } \\
\text { Details: } 1714 \text { STEMI patients } \\
\text { Variables: } 385 \text { in } 2010 \\
\text { Funding: Public and private, by French Society of Cardiology and several } \\
\text { pharmaceutical companies }\end{array}$ \\
\hline Sweden & $\begin{array}{l}\text { SWEDEHEART }[28,49] \\
\text { A collaboration (since 2008) of } \\
\text { RISK-HIA, SEPHIA, SCAAR, } \\
\text { Swedish Heart Surgery Registry } \\
\text { and Percutaneous Valve Registry }\end{array}$ & 2008 & $\begin{array}{l}\text { Covering: all } 74 \text { hospitals in Sweden for ACS patients undergoing CAG/ } \\
\text { PCI, percutaneous valve replacement or heart surgery. } \\
\text { Details: } 80.000 \text { new patients each year ( } 3 \text { million in total) } \\
\text { Variables: } 106 \text { variables ACS, } 75 \text { variables regarding secondary prevention, } \\
150 \text { variables for patients undergoing coronary angiography/angioplasty, } \\
100 \text { variables heart surgery. } \\
\text { Funding: Public, by the Swedish Association of Local Authorities and } \\
\text { Regions. Not linked with reimbursement }\end{array}$ \\
\hline Switzerland & $\begin{array}{l}\text { AMIS Plus [50] } \\
\text { Acute Myocardial Infarction in } \\
\text { Switzerland }\end{array}$ & 1997 & $\begin{array}{l}\text { Covering: } 106 \text { hospitals ( }>60 \% \text { ) in Switzerland with STEMI/NSTEMI, } \\
\text { voluntary participation } \\
\text { Details: } 33.040 \text { patients }(2010) \\
\text { Variables: } 230 \text { variables } \\
\text { Funding: Private, sponsored by several industries }\end{array}$ \\
\hline $\begin{array}{l}\text { United States } \\
\text { of America }\end{array}$ & $\begin{array}{l}\text { NCDR }{ }^{\circledR} \text { CathPCI }[27,28] \\
\text { National Cardiovascular Data } \\
\text { Registry }\end{array}$ & 1998 & $\begin{array}{l}\text { Covering: } 1577 \text { hospitals ( } 90 \% \text { of PCI-centres) in the United States } \\
\text { Details: } 12 \text { million patients. } \\
\text { Variables: } 250 \text { variables. } \\
\text { Funding: reimbursement by insurance companies for participating hospitals }\end{array}$ \\
\hline
\end{tabular}

the National Health Service, provides open access to information on treatment results of all individual cardiothoracic surgeons [36]. To improve transparency and to help patients in making informed decisions in the Netherlands, the aim of the Dutch government is to publish results of quality of care measurements at a national website for patients; www. kiesbeter.nl [3].

Pay-for-performance is the newest quality improvement mechanism, which is gaining attention from healthcare leaders and healthcare insurance companies as a strategy for maximising quality while controlling costs. Pay-forperformance implies a shift in paying for quality healthcare instead of volume of care, which can be a strong stimulus to improve quality $[31,37]$.

\section{Pitfalls in quality measurement}

As addressed before, the results of any measurement must be relevant for the different stakeholders in healthcare. In the current use and development of quality indicators it is also important to take into account that indicators are scientifically acceptable. The indicators should therefore be reliable and valid [38].

Reliable means that the indicator provides the same result on repeated measures and that the dataset is as complete as possible with uniform datasets which are collected in a uniform way. Also the Dutch Federation of University Medical Centres (Nederlandse Federatie van Universitair Medische Centra, NFU) points out in their report on a central vision on registration of care the value of a uniform standardised dataset. They aim to develop a uniform structure of elementary data elements and the use of a unified medical language based on international standards [39]. The use of universal definitions is encouraged by the International Consortium for Health Outcomes Measurement (ICHOM), an international non-profit organisation with the aim of transforming healthcare systems by measuring and reporting patient outcome [40]. 
Validity means that the indicator measures what it is intended to measure. This requires a good methodological quality, taking into account potential differences in casemix and random variation. A common remark heard by doctors is that they worry about case-mix correction and that a negative outcome compared with others can be explained by the more difficult patient population served. A good casemix correction applied in crude data could change the compared clinical outcome and is important to avoid unintended consequences [35, 41, 42]. Furthermore, it is important to remember that quality indicators are just an indication of the real quality of care. Therefore, the indicators should give appropriate coverage of the quality of care of a department and be in line with the crucial aspects of current strategies to improve quality of care.

\section{Future challenges}

On a national level, the current registries have to establish a unified collaboration and define useful indicators. NCDR, Meetbaar Beter and BHN are currently formalising this. It is intended that as of January 2016 NCDR and Meetbaar Beter will collaborate on the PCI database. On a regional level, hospitals should work together to acquire and exchange follow-up data, which requires commitment by the hospital's board of directors in measuring quality of care on a local level. Possibly this can be achieved by appointing a board member on quality of care, as proposed by the Dutch government. Secondly, feasibility is of major importance. Currently, hospitals and their departments deliver between 600 and 1000 quality indicators to external parties each year. Since possibilities for automatic computation are still limited in most hospitals, this task is extremely time consuming. This leaves little time to use these externally reported quality indicators for internal improvement programs. Indicators should be easy to register in daily practice and ideally automatically obtainable. For this, integration of hospital electronic patient file systems with the national registries is essential. To ensure a long-term and reliable registry, solid funding is crucial. However, next to this national funding, sufficient funding on a departmental level is vital, especially if implantation is expected to become mandatory. Finally, it has to be decided what level of transparency is useful to improve the quality of care.

\section{Conclusion}

The Dutch Minister of Healthcare has declared the year 2015 to be the year of transparency with the aim of improving healthcare by transparent reporting of quality of care. Furthermore, with the introduction of the regulated healthcare market, the position and role of the healthcare insur- ance companies provide an increasing focus on measuring quality of care. Initial thoughts are that quality indicators are connected with a lot of work without appreciating the benefits. Knowledge on and active participation in improving quality of care and quality measurements will be essential for cardiologists in daily clinical care. Active participation also offers major possibilities to design the most optimal quality measurement system and to take the lead in improving quality of care.

\section{Funding None.}

Disclosures Martin J. Schalij is a member of the Board of the National Cardiovascular Data Registry.

Bas A.J.M. de Mol is a member of the Board of Directors of Meetbaar Beter.

Giovanni Amoroso is a member of the Advisory Board of Meetbaar Beter.

Victor A.W.M. Umans is a member of the Board of Governors of the NCDR and Meetbaar Beter.

Open Access This article is distributed under the terms of the Creative Commons Attribution 4.0 International License (http://creativecommons.org/licenses/by/4.0/), which permits unrestricted use, distribution, and reproduction in any medium, provided you give appropriate credit to the original author(s) and the source, provide a link to the Creative Commons license, and indicate if changes were made.

\section{References}

1. The Dutch House of Representatives (Tweede Kamer der StatenGeneraal) 2003-2004. The Dutch House of Representatives 20032004, 29763 , no. $2 \& 3$.

2. Langejan T, Director of Dutch Healthcare Authority. Monitor on purchasing care (Monitor Zorginkoop). Report of the Dutch Healthcare Authority (Nederlandse Zorgautoriteit, NZa) 2014.

3. Schippers EI. Ministry of Health Welfare and Sport. Letter to House of Representatives: 2015 jaar van de transparantie. November 10, 2014.

4. Healthcare Insurance Act (Zorgverzekeringswet). 2005. http:// wetten.overheid.n1/BWBR0018450. Accessed 9 Feb 2015.

5. Arah O. Performance re-examined, concept, content and practice of measuring health system performance. Amsterdam: University of Amsterdam; 2005

6. Boot J. Organisatie van de gezondheidszorg. Assen: Koninklijke van Gorcum BV; 2010.

7. Kingdom of the Netherlands (Koninkrijk der Nederlanden). Dutch Constitution (Grondwet). Article 22: Health, Accommodation, Expansion (Volksgezondheid, Woongelegenheid, Ontplooiing). 1815.

8. Donabedian A. Evaluating the quality of medical care. Milbank Mem Fund Q. 1966;44(3):166-203.

9. Badheka A, Patel N, Grover P, Singh V, Patel N, Arora S. Impact of annual operator and institutional volume on percutaneous coronary intervention outcomes: a 5-year United States experience (2005-2009). Circulation. 2014;130(16):1392-406.

10. Peterson ED, Roe MT, Mulgund J, et al. Association between hospital process performance and outcomes among patients with acute coronary syndromes. JAMA. 2006;295:1912-20.

11. Choudry N, Glynn R, Avorn J, et al. Untangling the relationship between medication Am Heart J. 2014;167:51-8. 
12. Bradley EH, Herrin J, Elbel B, et al. Hospital quality for acute myocardial infarction: correlation among process measures and relationship with short-term mortality. JAMA. 2006;296:72-8.

13. Heidenreich PA, Hernandez AF, Yancy CW, Liang L, Peterson ED, Fonarow GC. Get With The Guidelines program participation, process of care, and outcome for Medicare patients hospitalized with heart failure. Circ Cardiovasc Qual Outcomes. 2012;5:37-43.

14. Court of Audit (Algemene Rekenkamer). Indicatoren voor kwaliteit in de zorg. March 28, 2013. Report No.

15. Dutch Healthcare Inspectorate (Inspectie voor de Gezondheidszorg IGZ). Basisset Ziekenhuizen 2015. Ministry of Health, Welfare and Sport, 2014.

16. Act of Regulation of Healthcare (Wet Marktordening Gezondheidszorg) 2006. http://wetten.overheid.nl/BWBR0020078. Accessed 9 Feb 2015

17. The Dutch House of Representatives (Tweede Kamer der StatenGeneraal) 2003-2004. Explanatory memorandum Healthcare Insurance Act. No. 29763.

18. Halbersma R, et al. Voldoen de verzekeraars in hun rol als motor van het zorgstelsel. Utrecht: Dutch Healthcare Authority (Nederlandse Zorgautoriteit, NZa); 2013.

19. Wierda E. The health market fails. Amsterdam: University of Amsterdam; 2013.

20. Langejan T. Director of Dutch Healthcare Authority. Letter to drs. E.J. Schippers, Minister of Health, Welfare and Sport. 2012.

21. Meurs P. The voice of insurers. Report of The Council for Public Health and Healthcare (Raad voor de Volksgezondheid en Zorg, RVZ). 2014

22. National Cardiovascular Data Registry. www.ncdr.nl. Accessed 20 Jan 2015

23. Ministry of Health Welfare and Sport. News article: Medische implantatenregister van start. January 30, 2015. Report No.

24. Begeleidingscomissie Hartinterventie Nederland (BHN). www. bhn-registratie.nl. Accessed 20 Jan 2015

25. Meetbaar Beter. www.meetbaarbeter.com. Accessed 20 Jan 2015.

26. NVVC Connect. www.nvvcconnect.nl. Accessed 20 Jan 2015.

27. Moussa I, Hermann A, Messenger J, et al. The NCDR CathPCI Registry: a US national perspective on care and outcomes for percutaneous coronary intervention. Heart. 2013;99:297-303.

28. McNamara RL, Chung SC, Jernberg T, et al. International comparisons of the management of patients with non-ST segment elevation acute myocardial infarction in the United Kingdom, Sweden, and the United States: the MINAP/NICOR, SWEDEHEART/ RIKS-HIA, and ACTION Registry-GWTG/NCDR registries. Int J Cardiol. 2014;175:240-7.

29. Herrett E, Smeeth L, Walker L, Weston C. The Myocardial Ischaemia National Audit Project (MINAP). Heart. 2010;96:1264-7.

30. Lauer MS, D'Agostino RB, Sr. The randomized registry trial - the next disruptive technology in clinical research? New Engl J Med. 2013;369:1579-81.

31. Chatterjee P, Joynt KE. Do cardiology quality measures actually improve patient outcomes? J Am Heart Assoc. 2014;3:e00404.

32. Haessler S. The Hawthorne effect in measurements of hand hygiene compliance: a definite problem, but also an opportunity. BMJ Qual Saf. 2014;23:965-7.

33. Joynt KE, Blumenthal DM, Orav EJ, Resnic FS, Jha AK. Association of public reporting for percutaneous coronary intervention with utilization and outcomes among Medicare beneficiaries with acute myocardial infarction. JAMA. 2012;308:1460-8.
34. Narins CR, Dozier AM, Ling FS, Zareba W. The influence of public reporting of outcome data on medical decision making by physicians. Arch Intern Med. 2005;165:83-7.

35. Wasfy JH, Borden WB, Secemsky EA, McCabe JM, Yeh RW. Public reporting in cardiovascular medicine: accountability, unintended consequences, and promise for improvement. Circulation. 2015;131:1518-27.

36. Society for Cardiothoracic Surgery in Great Britain and Ireland. Find a Cardiothoracic Centre of Surgeon. www.scts.org/modules/ surgeons. Accessed 20 Jan 2015.

37. Kristensen SR, Meacock R, Turner AJ, et al. Long-term effect of hospital pay for performance on mortality in England. New Engl J Med. 2014;371:540-8.

38. Dimick JB. What makes a "good" quality indicator? Arch Surg. 2010;145:295.

39. Hazelzet J, Georgieva P. Registratie aan de bron. Visie op documentatie en gebruik van zorggegevens 2013-2020. Nederlandse Federatie van Universitair Medische Centra (NFU), 2013 April, 2013. Report No.

40. International Consortium for Health Outcomes Measurement (ICHOM). www.ichom.org. Accessed 17 Mar 2015

41. Denvir MA, Lee AJ, Rysdale J, et al. Comparing performance between coronary intervention centres requires detailed case-mix adjusted analysis. J Public Health. 2004;26:177-84.

42. Davenport RJ, Dennis MS, Warlow CP. Effect of correcting outcome data for case mix: an example from stroke medicine. BMJ. 1996;312:1503-5.

43. Birkmeyer JD, Dimick JB, Birkmeyer NJ. Measuring the quality of surgical care: structure, process, or outcomes? J Am Coll Surg. 2004;198:626-32.

44. Belgian Interdisciplinary Working Group on Acute Cardiology (BIWAC). Belgian STEMI Registry. www.biwac.be; www.biwacstemi.be. Accessed 17 Mar 2015.

45. Claeys M, Gevaert S, De Meester A, et al. Implementation of reperfusion therapy in ST-segment elevation myocardial infarction. A policy statement from the Belgian Society of Cardiology (BSC), the Belgian Interdisciplinary Working Group on Acute Cardiology (BIWAC) and the Belgian Working Group on Interventional Cardiology (BWGIC). Acta Cardiol. 2009;64:541-5.

46. Belgian Working Group Interventional Cardiology. www.BWGIC. org. Accessed 17 Mar 2015.

47. Danchin N, Coste P, Ferrieres J, et al. Comparison of thrombolysis followed by broad use of percutaneous coronary intervention with primary percutaneous coronary intervention for ST-segment-elevation acute myocardial infarction: data from the French registry on acute ST-elevation myocardial infarction (FAST-MI). Circulation. 2008;118:268-76.

48. Cambou JP, Simon T, Mulak G, Bataille V, Danchin N. The French registry of Acute ST elevation or non-ST-elevation Myocardial Infarction (FAST-MI): study design and baseline characteristics. Arch Mal Coeur Vaiss. 2007;100:524-34.

49. Jernberg T, Attebring MF, Hambraeus K, et al. The Swedish Websystem for enhancement and development of evidence-based care in heart disease evaluated according to recommended therapies (SWEDEHEART). Heart. 2010;96:1617-21.

50. Radovanovic D, Erne P. AMIS Plus: Swiss registry of acute coronary syndrome. Heart. 2010;96:917-21. 